\title{
Article \\ Fiber-Type Influence on the Flexural Behavior of RC Two-Way Slabs with an Opening
}

\author{
Haleem K. Hussain *, Abdulnasser M. Abbas and Mohammed Farhan Ojaimi
}

Citation: Hussain, H.K.; Abbas, A.M.; Ojaimi, M.F. Fiber-Type Influence on the Flexural Behavior of RC Two-Way Slabs with an Opening. Buildings 2022, 12, 279. https://doi.org/ 10.3390 /buildings12030279

Academic Editor: Alessandra Aprile

Received: 20 January 2022

Accepted: 26 February 2022

Published: 1 March 2022

Publisher's Note: MDPI stays neutral with regard to jurisdictional claims in published maps and institutional affiliations.

Copyright: (C) 2022 by the authors. Licensee MDPI, Basel, Switzerland. This article is an open access article distributed under the terms and conditions of the Creative Commons Attribution (CC BY) license (https:// creativecommons.org/licenses/by/ $4.0 /)$.
Civil Engineering Department, Engineering College, University of Basrah, Basrah 61004, Iraq; abdulnasser.abbas@uobasrah.edu.iq (A.M.A.); mohammed.ojaimi@uobasrah.edu.iq (M.F.O.)

* Correspondence: haleem.hussain@uobasrah.edu.iq or haleem.albremani@gmail.com

\begin{abstract}
Combining fiber with concrete mixes has become essential and its widespread use improves the strength of structural concrete elements. This research conducted an experiment into the structural performance of flat slabs with and without a square opening using four types of fiber (hooked-end, straight, corrugated steel fiber and polyolefin fiber) to gain a better understanding of how the variance of fiber type and shape effects the flexural behaviors of two-way slabs. The test program involved (a) testing the properties of hardened concrete, such as compressive properties, modulus of rupture and splitting tensile strength, and (b) testing the flexural behavior of two-way slabs. Ten slabs were divided into five pairs, including two specimens used as reference specimens (with and without openings), and eight other specimens with different types of fibers. Results revealed that the existing fiber in concrete improved the mechanical properties of hardened concrete mix, and the compressive strength test showed higher improvement in specimens with hooked and straight steel fiber. The flexural behavior of reinforced concrete slab was significantly enhanced, and the flexural strength capacity was especially improved for the slabs strengthened with hooked-end and corrugated steel fiber. Polyolefin fiber showed a slight enhancement of mechanical properties and good improvement in flexural capacity. Generally, the highest increments in compressive strength and modulus of rupture were $24.8 \%, 20 \%$ and $11 \%$, and the ultimate load-carrying capacity of slabs was $39 \%, 13 \%$ and $19 \%$ for specimens with steel hooked, steel corrugated and polyolefin fibers, respectively, coMPared with control specimens.
\end{abstract}

Keywords: steel fiber; polyolefin fiber; flexural behavior; two-way slab; slab with opening

\section{Introduction}

The recent advances made in polymer material development have had a positive effect in engineering technology. The constructions and materials fields make the most use of these technologies. Polyolefin, poly-propylene and polyethylene have undergone extensive and fast development in the last decades [1].

David Fall et al. [2] investigated the effect of fibers on the structural behavior of four edges simply supported by a two-way reinforced concrete slab, such as in crack patterns and load-carrying capacity. Double hook-end steel fibers were used, and three slab samples were loaded with a central point load. The results showed significant effects on structural behavior through providing post-cracking ductility, with an improvement in loading capacity around $20 \%$. Furthermore, the tested sample showed load redistribution in a manner that allowed more load to be transferred to the support in the weak direction.

Szymon Grzesiak et al. [3] and recent research on concrete reinforced with fiber in general show that the ratio of added fiber to concrete improves the energy absorption capacity of concrete which leads to improving the strength of the concrete structure. The study was conducted into the mechanical properties of high-performance fiber-reinforced concrete (HPFRC) for different types and different percentages of polymer fiber. The flexural tensile strength was investigated using a square panel and a beam. For both 
types of fiber, an increase was shown in the splitting tensile strength of concrete mixes. Meanwhile, compressive strength decreased with increasing fiber ratio coMPared with control samples, and flexural tests proved that using polyvinyl alcohol fiber (PVA) gives higher ductility behaviors.

Altun et al. [4] presented the flexural behavior of a reinforced concrete box using steel fiber beams of normal concrete strength (22 MPa compressive strength) and $6 \mathrm{~cm}$ lengths of steel fiber, with a volume ratio of 0.77 . The results show a decrease of around $44 \%$ of the weight. In addition, the load capacity was reduced by $29 \%$.

Dapeng Yang et al. [5] submitted a considerable experimental study on concrete slab reinforced with steel fiber against spall. Furthermore, they investigated the mechanical properties of different concrete mixes with different fiber ratios. In general, the mechanical properties showed a similarity with the results of other research, while in a field explosion conducted to study the dynamic response and damage modes, the results presented a good resistance to spall, especially the concrete reinforced with hooked steel fiber, where with an increase in the length of fiber and in the volume of the fiber ratio, the spall resistance was significant improved.

Most concrete composite structural elements can have substantial ductility. In general, the ductility is dependent on fiber type, fiber ratio, anchorage mechanism and tensile strength. The enhancement of ductility is taken into account when determining the thickness of floors. The calculation for floor thickness design takes into account the first post crack due to flexural strength in positive (sagging) moment capacities, while the effect of fibers is neglected regarding negative moment strength [6].

Kosa and Naaman (1990) [7] concluded that long-term environmental exposure to salt solutions significantly reduced the crack performance of steel-fiber-reinforced concrete (FRC) due to the decrease in fibers as they are corroded at the cross section. In short-term exposure conditions in salt solution, post-peak residual strengths at low levels of tensile and flexural strains were found to be higher coMPared with control specimens.

Polyolefin fiber is made of either high-density polyethylene or from polypropylene. In general, the fiber length is 3 to $6 \mathrm{~cm}$ and the sectional area around $0.6-1.5 \mathrm{~mm}^{2}$. The mechanical properties generally include a tensile strength of 300 to $600 \mathrm{~N} / \mathrm{mm}^{2}$ and a modulus of elasticity of about 4 to $10 \mathrm{GPa}$ [8]. Two techniques have been frequently used to fabricate macro polyolefin fiber. The first technique involves melt-spinning polyolefin granules into strings and then hot-working the monofilaments into fibers [9]. The polyolefin fiber density is around $0.9 \mathrm{~g} / \mathrm{cm}^{3}$, which is less than the density of steel fiber $\left(7.8 \mathrm{~g} / \mathrm{cm}^{3}\right)$. The small volume ratio of either steel fiber or polyolefin fiber in concrete have no significant effect on the total weight of the concrete [10].

Recently, much essential research has addressed the sustainability of material production, especially regarding large-scale production such as that of cement and concrete mixes. This also includes the use of fibers in concrete structural elements, as well as in several other fields. However, most studies did not consider the indirect costs such as social and environmental effects, and took into account only the direct cost of the materials used. Dong et al. [11] studied the flexural behavior of deck plates using micro-synthetic-fiberreinforced concrete, and initially studies into the mechanical properties were conducted. The flexural strength showed enhancement coMPared with normal concrete specimens, and in maximum strength tests, the specimens showed a residual strength fracture. The strength capacity of deck slabs and the cracking load were increased with increasing fiber ratio.

Alireza et al. [12] undertook a specific test program into the water permeability of plain and fiber-reinforced concrete through exploring crack behavior (width, length, tortuosity and surface roughness). The results show that concrete permeability is a function of crack permeability, as well as that of the roughness and tortuosity of crack. The presence of fiber reduced the permeability due to reducing crack tortuosity and the friction caused by crack surface roughness.

Lijuan Zhang et al. [13] investigated the effect of the shape of steel fiber (straight, corrugate and hooked) and volume ratio with different volume fractions $(0,0.5 \%, 1 \%, 1.5 \%$, and $2 \%$ ) on 
mechanical properties including the flexural strength of a prism. The results proved that the shape of the steel fiber had a significant effect on flexural strength. Corrugated and hooked-end steel showed higher improvement in flexural strength due to generating a good bridging action in the concrete matrix. Deformed steel fibers had a greater iMPact than those with a straight shape.

Arkadiusz Denisiewicz and Tomasz Socha [14] studied the mechanical and physical properties of fine-grained fiber concrete. Two types of fiber were used: steel fiber and polypropylene fibers. The concrete mixture samples were tested for slump class, bending, shrinkage, compressive strength and water tightness. The results revealed that the steel fiber had a small effect on workability coMPared with polypropylene, and that steel fiber decreased the shrinkage whereas polypropylene fibers significantly increased the concrete shrinkage. The positive effect of polypropylene was increasing the bending and compressive strength of concrete samples.

Petr L. and Marie H. [15] presented a numerical study of concrete samples exposed to chlorides, in relation to the service life of lightweight waste structural members. The study used different types of waste material to produce lightweight concrete, such as red clay and red ceramics, with steel fiber at different percentages. The main factors studied were the constant diffusion coefficient and time-dependent diffusion coefficient, to analyse the effects on the service life of the structure. Based on their results, it was found that more fibers reduce the service life and preloading of the structure.

Many field applications are now widespread and used frequently, such as using fiber-reinforced polymers in concrete structure elements due to improvements in flexural behavior. These fiber polymers are used as bars or as sheets (such as FRP, GFRP and BFRP bars) to enhance the flexural behavior of slabs, panels, columns and beams. The research was verified by theoretical analysis and is considered to align with international standards. BFRP with polymer cement composite is also widely used in strengthening concrete structural elements such as slabs and bridge decks due to damage and degradation in the material with time. Outcomes reveal good bonding and a reduction in crack width, and enhanced flexural capacity [16,17].

The design standards and codes specify mechanical requirements for structural use. Therefore, those fibers capable of complying with the standards for residual strengths are called structural fibers, and are normally macro-steel fibers.

\section{Materials and Experimental Work}

\subsection{Materials}

\subsubsection{Cement}

Ordinary Portland cement (type I) was available in the local market (Mabroka) and was manufactured by an Iraqi coMPany. The physical and chemical properties were established in the engineering college laboratory at the University of Basrah and are shown in Tables 1 and 2.

Table 1. Chemical composition and main components of cement.

\begin{tabular}{cccccccccccccc}
\hline \multicolumn{1}{c}{} & \multicolumn{1}{c}{ Chemical Components of Cement } & \multicolumn{4}{c}{ Main Components of Cement } \\
\hline $\mathrm{SiO}_{2}$ & $\mathrm{Al}_{2} \mathrm{O}_{3}$ & $\mathrm{Fe}_{2} \mathrm{O}_{3}$ & $\mathrm{CaO}$ & $\mathrm{MgO}$ & $\mathrm{Na}_{2} \mathrm{O}$ & $\mathrm{K}_{2} \mathrm{O}$ & $\mathrm{SO}_{3}$ & $\begin{array}{c}\text { Insoluble } \\
\text { Residue }\end{array}$ & $\mathrm{LOI}$ & $\mathrm{C}_{3} \mathrm{~S}$ & $\mathrm{C}_{2} \mathrm{~S}$ & $\mathrm{C}_{3} \mathrm{~A}$ & $\mathrm{C}_{4} \mathrm{AF}$ \\
\hline 20.7 & 5.3 & 3.9 & 62.8 & 1.94 & 0.35 & 0.66 & 1.96 & 0.47 & 1.4 & 50.2 & 24.3 & 6.81 & 10.5 \\
\hline
\end{tabular}


Table 2. Physical properties of cement.

\begin{tabular}{|c|c|c|c|c|}
\hline Property & Standard & Test Method & Unit & Result \\
\hline \multirow{2}{*}{ Fineness } & \multirow{2}{*}{ ASTM C204 [18] } & Mesh 170 & $\%$ & $6.4 \%$ \\
\hline & & Blaine air permeability & $\left(\mathrm{m}^{2} / \mathrm{kg}\right)$ & 309 \\
\hline \multirow{2}{*}{ Setting time } & \multirow{2}{*}{ ASTM C191 [19] } & Initial & minute & 135 \\
\hline & & Final & minute & 260 \\
\hline \multirow{2}{*}{$\begin{array}{l}\text { Compressive } \\
\text { strength }\end{array}$} & \multirow{2}{*}{ ASTM-C349 [20] } & 3 days & $\mathrm{MPa}$ & $19.2 \mathrm{MPa}$ \\
\hline & & 7 days & $\mathrm{MPa}$ & $26.3 \mathrm{MPa}$ \\
\hline
\end{tabular}

\subsubsection{Aggregate}

Local crushed coarse aggregates and fine aggregate (sand) were provided from the $\mathrm{Al}$ Zubair area, which lies in south of Iraq. The gradations for fine and coarse aggregates are shown in Figure 1. The grading was tested according to ASTM C33/86 [21].

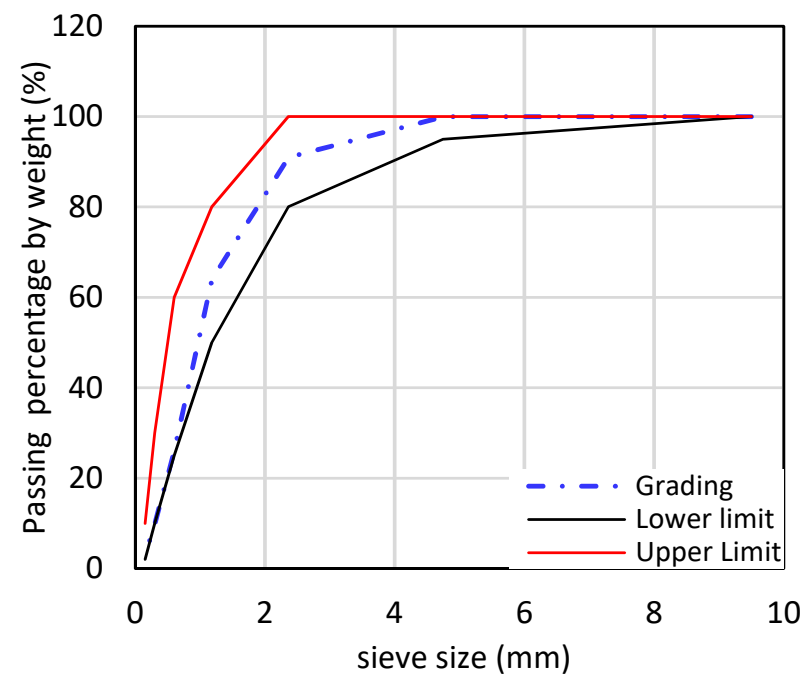

(a)

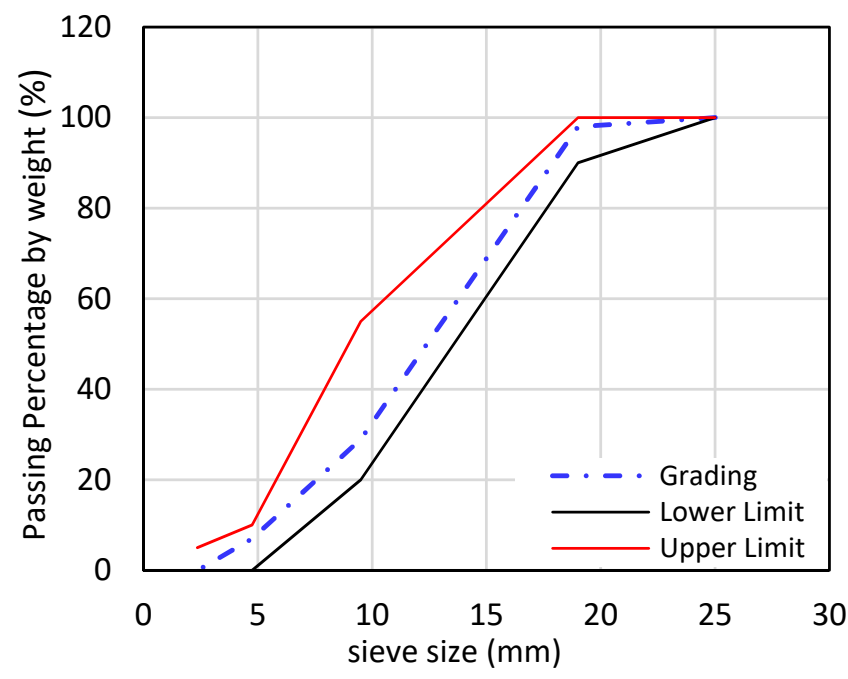

(b)

Figure 1. Aggregate grading as: (a) Fine aggregate grading; (b) Coarse aggregate grading.

The physical properties of course aggregate and fine aggregate are listed in Table 3 and were tested according to the ASTM C 128 [22].

Table 3. Physical properties of aggregate.

\begin{tabular}{ccccccc}
\hline $\begin{array}{c}\text { Aggregate } \\
\text { Type }\end{array}$ & $\begin{array}{c}\text { Bulk Specific } \\
\text { Gravity (SSD) }\end{array}$ & $\begin{array}{c}\text { Apparent } \\
\text { Specific } \\
\text { Gravity }\end{array}$ & $\begin{array}{c}\text { Dense Dry } \\
\text { Density } \\
\mathbf{( k g / \mathbf { m } ^ { 3 }}\end{array}$ & $\begin{array}{c}\text { Loose Dry } \\
\text { Density } \\
\mathbf{( k g / \mathbf { m } ^ { 3 } )}\end{array}$ & $\begin{array}{c}\text { Sulphate } \\
\text { Content (\%) }\end{array}$ & $\begin{array}{c}\text { Absorption } \\
(\mathbf{\%})\end{array}$ \\
\hline Coarse Aggregate (gravel) & 2.46 & 2.50 & 1620 & 1468 & - & 0.89 \\
\hline Fine Aggregate (sand) & 2.68 & 2.74 & 1871 & 1722 & 0.24 & 1.62 \\
\hline
\end{tabular}

\subsubsection{Fibers}

The polyolefin and steel fiber properties are listed in Table 4. Figure 2 shows the type and shape of steel and polyolefin fibers. 
Table 4. Properties of fibers used.

\begin{tabular}{|c|c|c|c|c|c|}
\hline Fiber Type & Shape & Length (mm) & Diameter (mm) & $\begin{array}{l}\text { Aspect Ratio } * * \\
(\mathrm{~mm})\end{array}$ & $\begin{array}{c}\text { Tensile Strength } \\
\text { (MPa) }\end{array}$ \\
\hline Straight steel fiber & Straight & 12 & 0.25 & 50 & 2850 \\
\hline Hooked steel fiber & Hooked & 30 & 0.5 & 60 & $>1000$ \\
\hline $\begin{array}{c}\text { Corrugated steel } \\
\text { fiber }\end{array}$ & Corrugated & 30 & $0.55 *$ & 55 & $>700$ \\
\hline Polyolefin fiber & - & 60 & 0.84 * & 71 & 465 \\
\hline
\end{tabular}

${ }^{*}$ : equivalent diameter, ${ }^{* *}$ : (Length/Diameter).

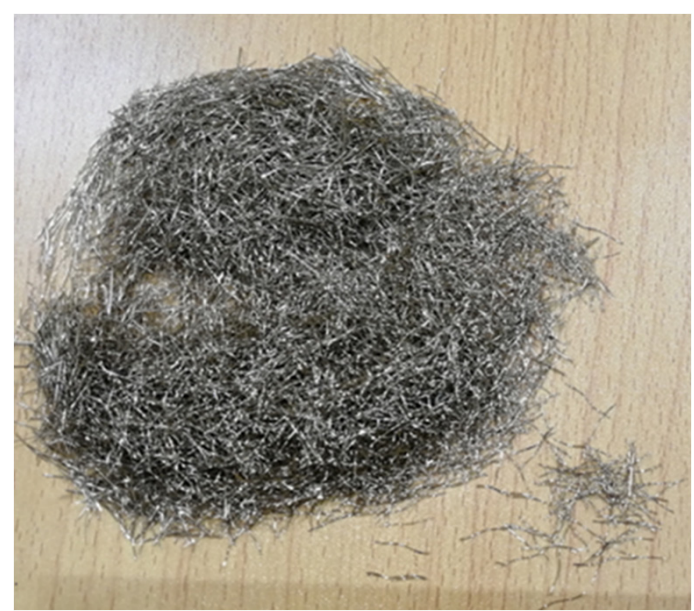

(a)

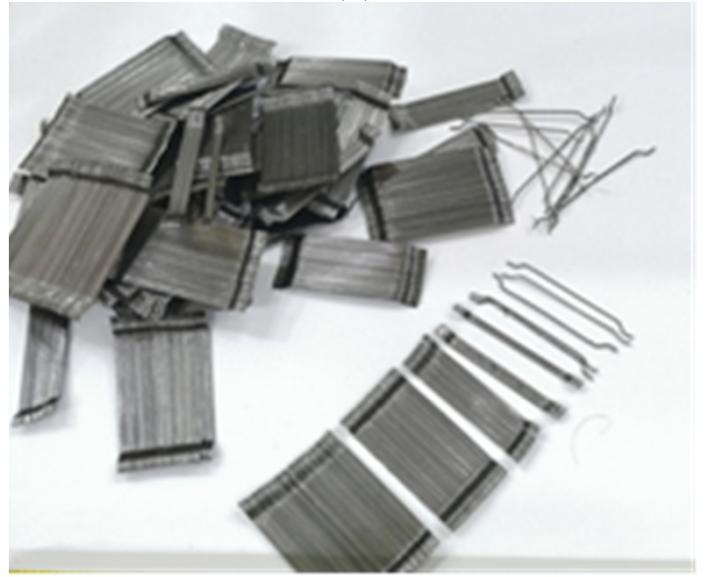

(c)

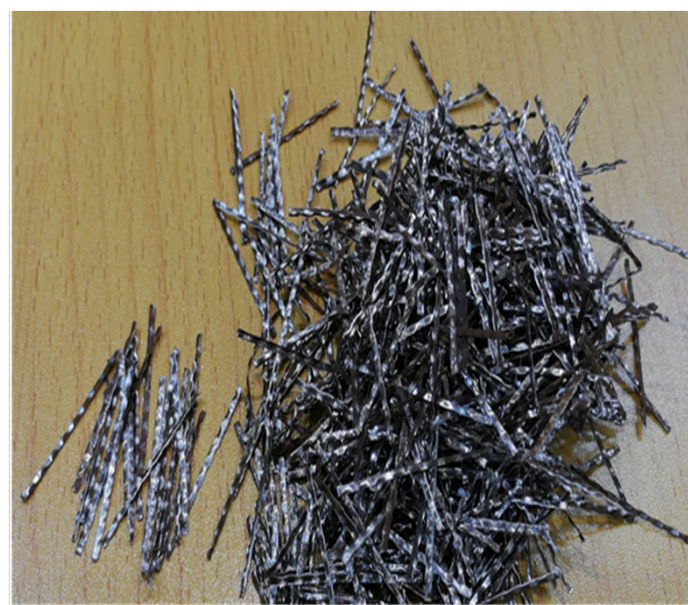

(b)

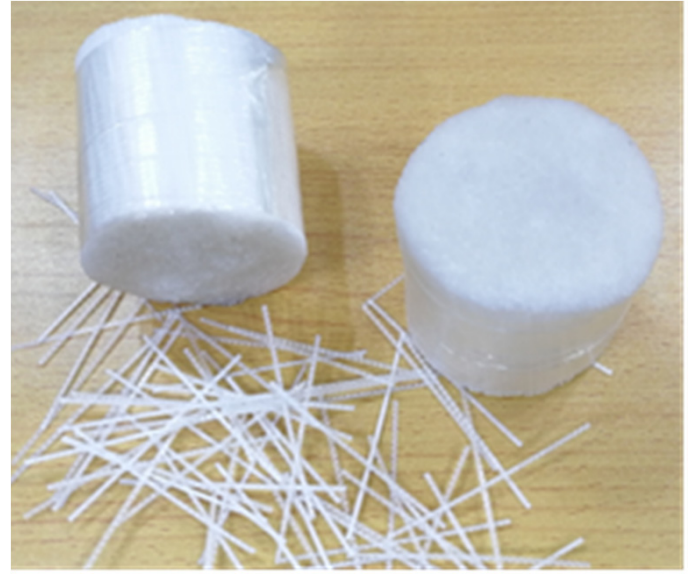

(d)

Figure 2. Types of fibers: (a) Straight steel fiber; (b) Corrugated steel fiber; (c) Hooked steel fiber; (d) Polyolefin fiber.

\subsubsection{Mix Proportion}

ViscoCrete (F-180 G) superplasticizer was used as an additive to mix the formula in accordance with ASTM C494 [23], at a percentage of $0.6 \%$ of the total cement weight. Tap water from Basrah city was used. The mix proportion used in this experiment is listed in Table 5. 
Table 5. Mix proportion quantities.

\begin{tabular}{cccccc}
\hline Cement (kg) & $\begin{array}{c}\text { Fine Aggregate } \\
\left(\mathbf{k g} / \mathbf{m}^{\mathbf{3}}\right)\end{array}$ & $\begin{array}{c}\text { Fine Aggregate } \\
\left(\mathbf{k g} / \mathbf{m}^{\mathbf{3}}\right)\end{array}$ & Water $\mathbf{( k g / \mathbf { m } ^ { 3 } )}$ & Fiber $\left(\mathbf{k g} / \mathbf{m}^{3}\right)$ & $\begin{array}{c}\text { Super Plasticizer } \\
(\mathbf{k g})\end{array}$ \\
\hline 370 & 740 & 1110 & 181 & 3.7 & 2.22 \\
\hline
\end{tabular}

\subsection{Sample Preparation}

\subsubsection{Mechanical Properties}

The same percentages of the four fibers were used in all samples with a constant ratio $(1 \% \mathrm{Vf})$. These percentages were chosen based on previous research, and varied between $0.5 \%$ and $2 \%$, which is the correct ratio to provide a suitable consistency and workability for fresh concrete mixes. The mechanical properties were tested for each type of fiber (compressive strength, modulus of rupture and tensile strength). The samples were prepared according to the ASTM C192 [24].

Three cylindrical samples $(150 \times 300 \mathrm{~mm})$ were prepared as compressive strength test cylinders for each mix according to the ASTM C39 [25]. A splitting tensile strength test was conducted using a cylinder with dimensions $150 \mathrm{~mm}$ diameter and $300 \mathrm{~mm}$ height to comply with standard specification ASTM C496 [26]. Furthermore, three prism samples were prepared for each mix to conduct flexural strength tests. The prism dimensions were $500 \times 150 \times 150 \mathrm{~mm}$ according to ASTM C78/C78M [27].

After $24 \mathrm{~h}$, all prepared specimens were demolded and kept in water at a temperature of $20^{\circ} \mathrm{C}$ continuously for 28 days until the time of the test.

\subsubsection{Two-Way Slab Details}

The dimensions of the two-way slabs were $800 \times 800 \times 100 \mathrm{~mm}$. They were reinforced with $\varphi 12 \mathrm{~mm}$ in both directions (5 bars in each direction) with concrete covering $25 \mathrm{~mm}$. The yield stress of the steel bar used was $428 \mathrm{MPa}$ with ultimate stress Fu equal to $543 \mathrm{MPa}$, and the strain yield was $(0.00226)$. The slab was supported by a steel frame $(700 \times 700 \mathrm{~mm})$ providing a $700 \mathrm{~mm}$ clear span in two directions. Figure 3 gives detail of the geometry and reinforcement of the slab sample. The slab had an opening $(150 \times 150 \mathrm{~mm})$ at the center of panel and loads were applied on a steel plate with the dimensions $200 \times 200 \mathrm{~mm}$ at the center.

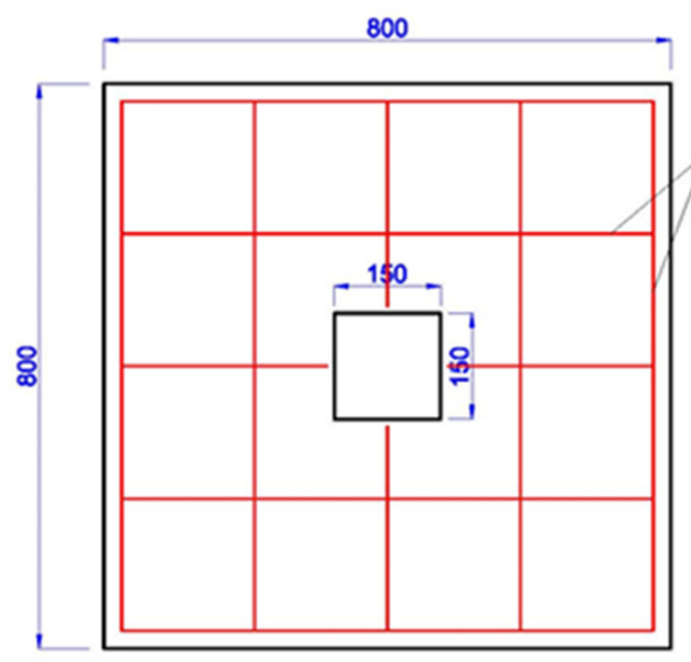

(a) Slab with opening

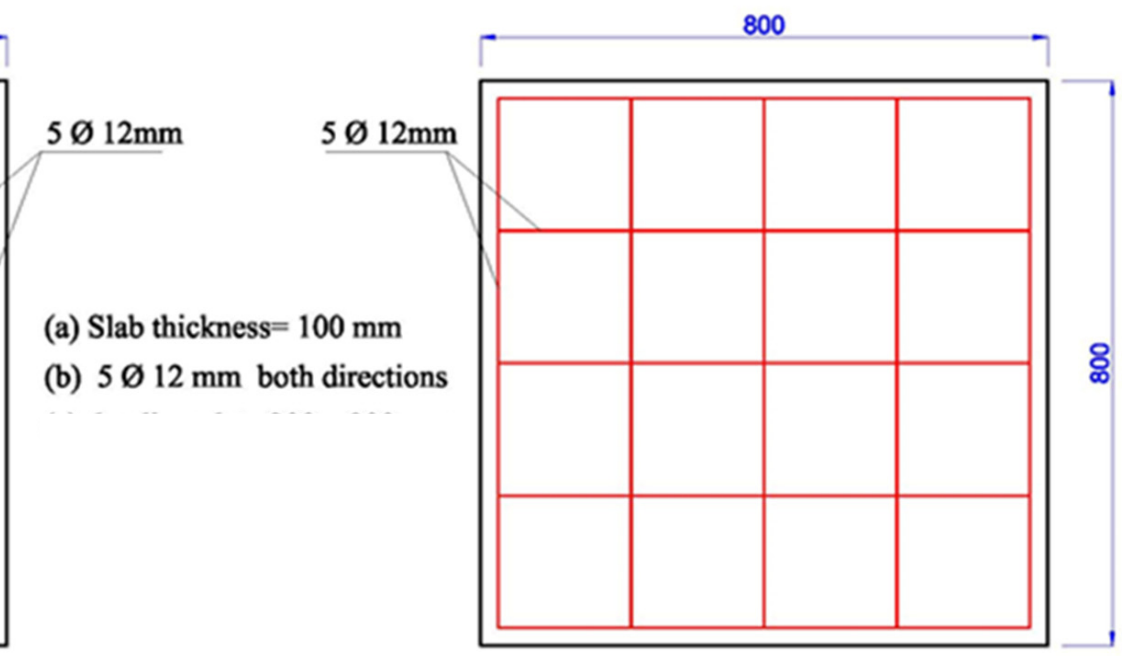

(b) Solid Slab

Figure 3. Two-way reinforced slab details ( $\mathrm{mm}$ ) as: (a) slab with opening; (b) solid slab.

Figure 4 shows the wooden mold before casting concrete and also shows the test devices setup, the universal machine of applied load and the frame support of the slab. 


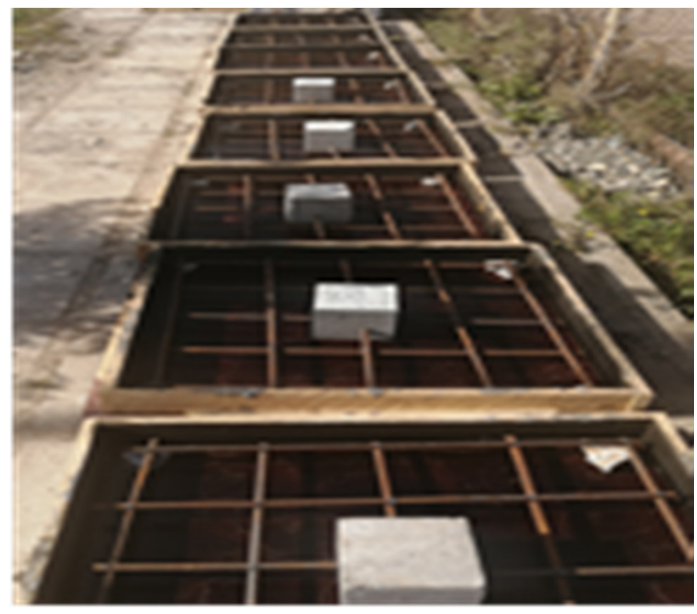

(a)

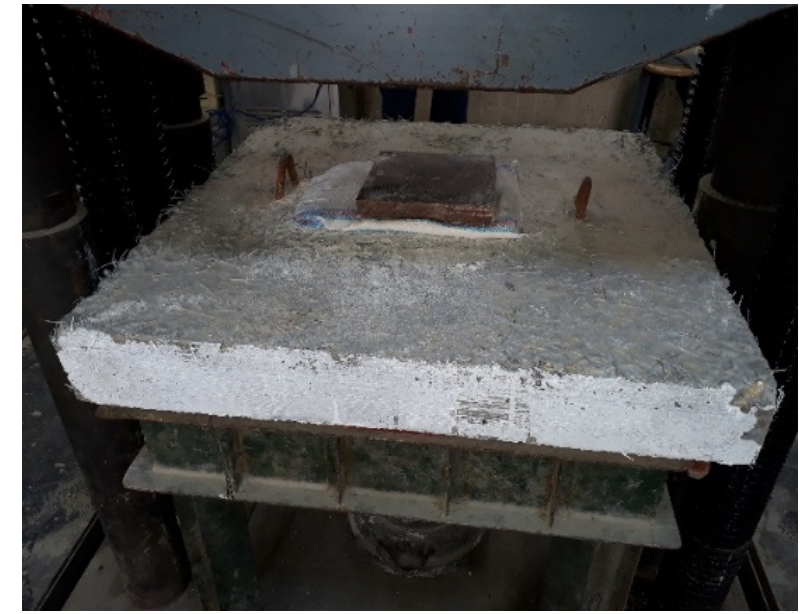

(b)

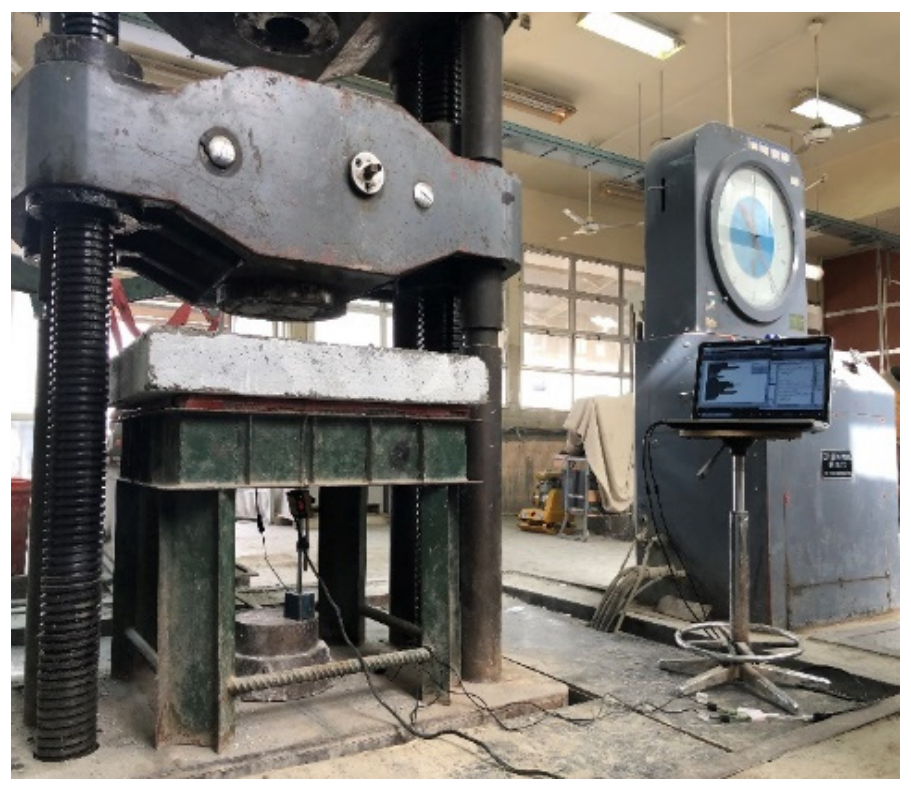

(c)

Figure 4. Work process as: (a) Wooden form of slab; (b) Loading plate; (c) Loading setup schematic and measurement devices.

\section{Mechanical Properties Results}

In general, steel fibers in concrete produce a moderate enhancement of compressive strength. The fibers used in the concrete mixes increased the compressive strength by around $24.8 \%, 20 \%, 22 \%$, and $11.3 \%$ for straight, hooked, corrugated, and polyolefin fibers, respectively, coMPared with control specimens. Fibers increased the absorption of energy or improved ductility and the steel fiber produced higher compressive strength. Because steel fiber is stiff and well-bonded, it could better prevent micro-cracks from developing in samples coMPared with polyolefin fiber. Results are listed in Table 6 and Figure 5a.

Table 6 and Figure $5 \mathrm{~b}$ present the modulus of rupture and it can be seen that there is a remarkable improvement in the bending capacity of the prism reinforced with fiber, and that this improvement is greater than that of other properties. Increases of about $109 \%, 78 \%$ and $62 \%$ for steel hooked, steel corrugated and polyolefin fiber, respectively, can be seen. Initially, the fiber improves the toughness or energy absorption capacity. As previously indicated, the higher bond and friction between fiber and concrete matrix lead to improvements in the flexural strength.

The splitting tensile strength of concrete modified with fiber shows significant enhancement due to the generation of a strong interlock between the fiber and concrete 
matrix, especially with the hooked-end and corrugated steel fiber. The higher increment ratio in splitting tensile strength was $94 \%$ and $77 \%$ for hooked and corrugated steel fiber, respectively, coMPared with plain concrete, as shown in Figure $5 \mathrm{c}$.

Table 6. Mechanical properties tested results of mixes.

\begin{tabular}{ccccc}
\hline Sample Type & Symbols & $\begin{array}{c}\text { Compression } \\
\text { Cylinder Test (MPa) }\end{array}$ & $\begin{array}{c}\text { Modulus of Rupture } \\
\text { (MPa) }\end{array}$ & $\begin{array}{c}\text { Splitting Tensile } \\
\text { Strength (MPa) }\end{array}$ \\
\hline Without fiber (control) & control & 36.2 & 4.20 & 2.32 \\
\hline Straight steel fiber $12 \mathrm{~mm}$ & S-1 & 45.2 & 6.38 & 3.81 \\
\hline Hooked steel fiber $30 \mathrm{~mm}$ & H-1 & 43.5 & 8.76 & 4.51 \\
\hline Corrugated steel fiber $30 \mathrm{~mm}$ & C-1 & 44.2 & 7.49 & 4.12 \\
\hline Polyolefin fiber $60 \mathrm{~mm}$ & P-1 & 40.3 & 6.80 & 3.12 \\
\hline
\end{tabular}

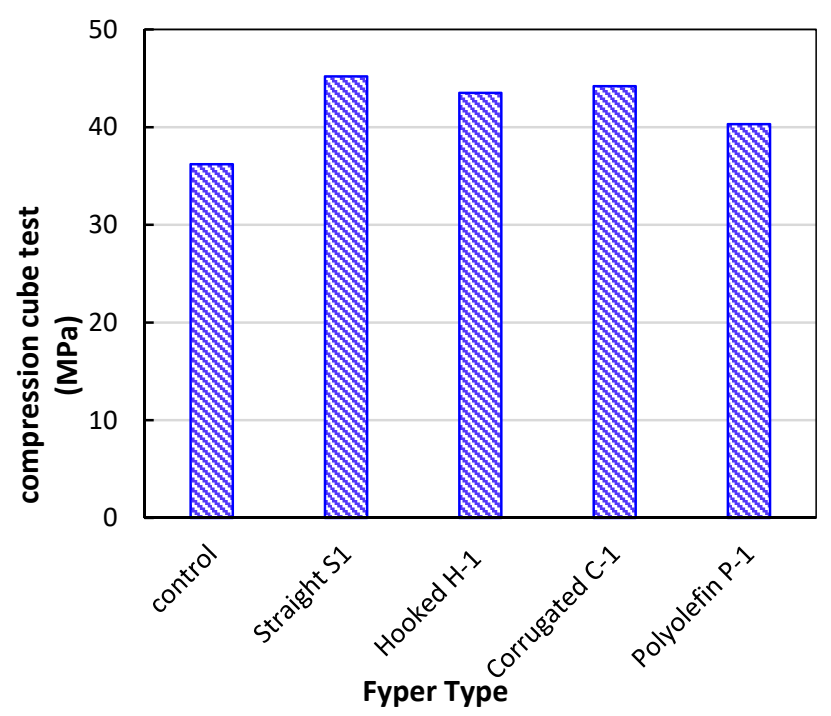

(a)

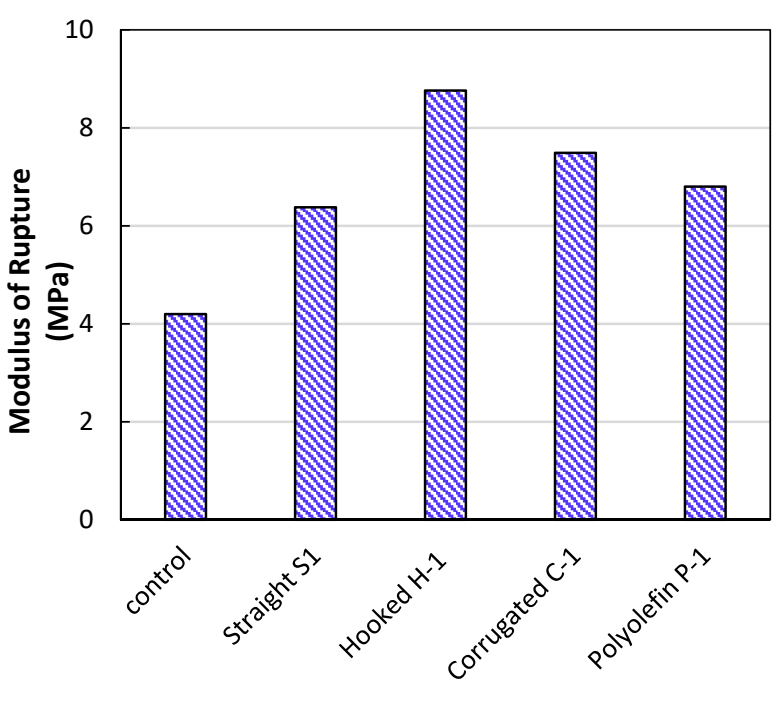

Fyper Type

(b)

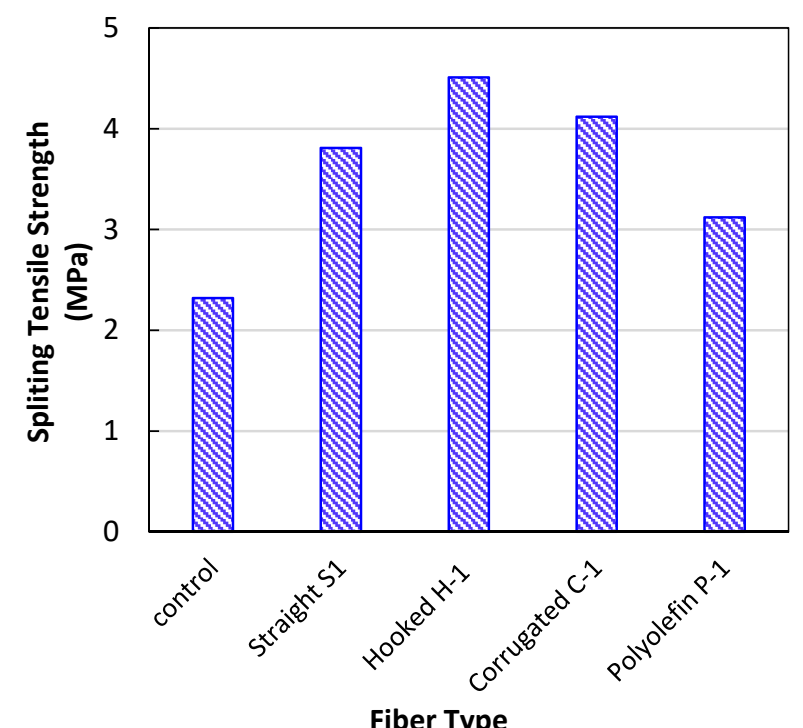

(c)

Figure 5. Mechanical properties of concrete mix with fiber as: (a) Compression cube test; (b); Modulus of rupture; (c) Splitting tensile strength. 


\section{Failure Modes and Crack Patterns}

All experimentally tested specimens are shown in Figure 6. Diagonal cracks at the bottom surface started from the corners of the opening and propagate from the center toward the corners of the slabs, and all specimens failed in flexural patterns. On the control specimen with an opening, cracks spread widely and were accoMPanied by a minor, narrow, short crack in addition to the main cracks across the whole slab. In the other specimens with steel fiber, fewer cracks were generated from the corners of openings towards the corner of slab which indicated a greater increase in the stiffness of the slab and led to a higher ultimate load coMPared with the control specimen. The slab with polyolefin showed more ductile behavior and the crack devolved much more than those in the specimens with steel fiber.

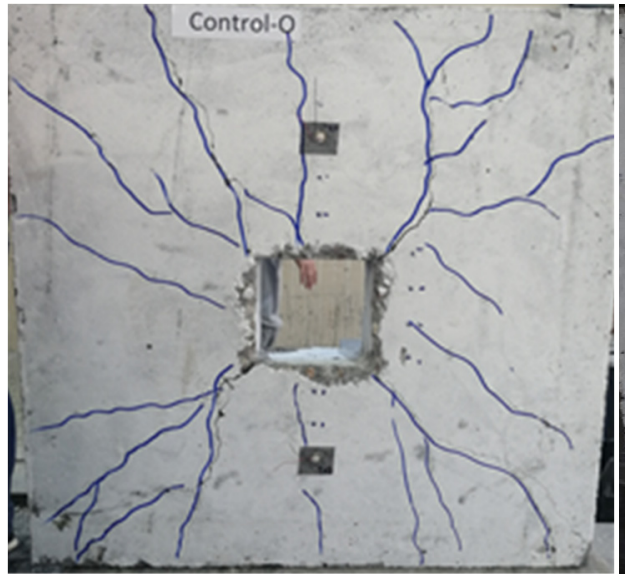

(a)

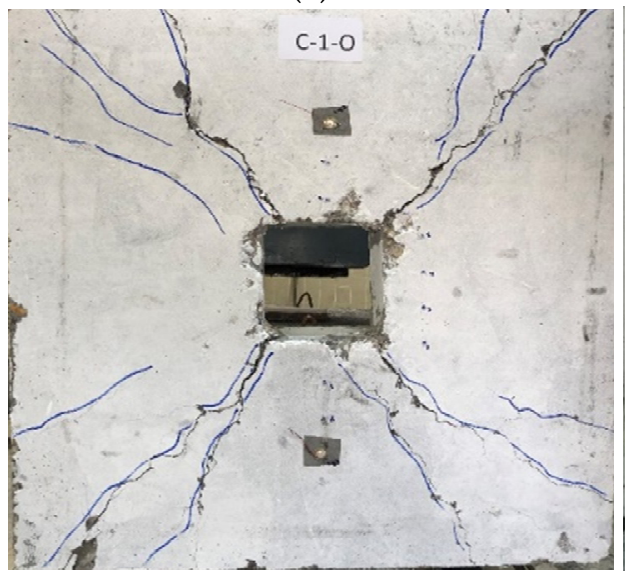

(d)

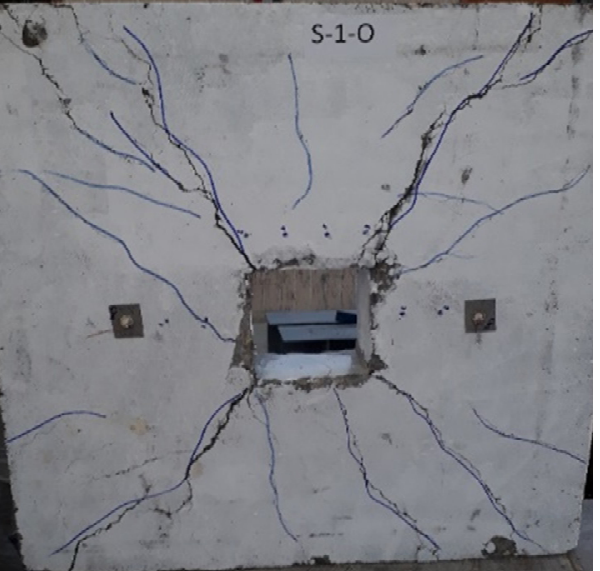

(b)

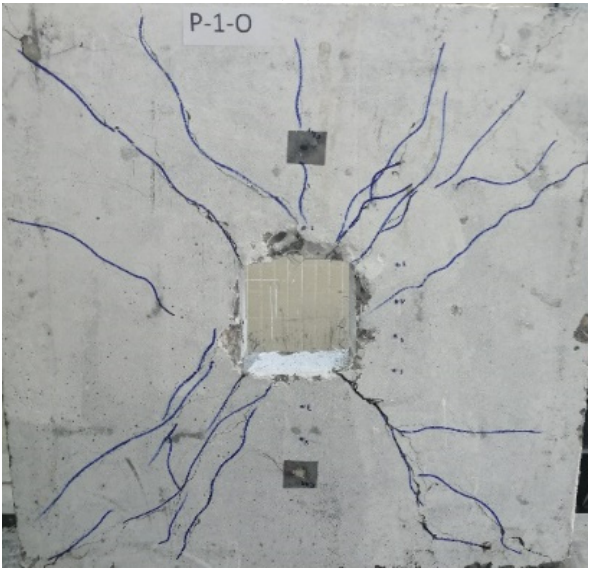

(e)

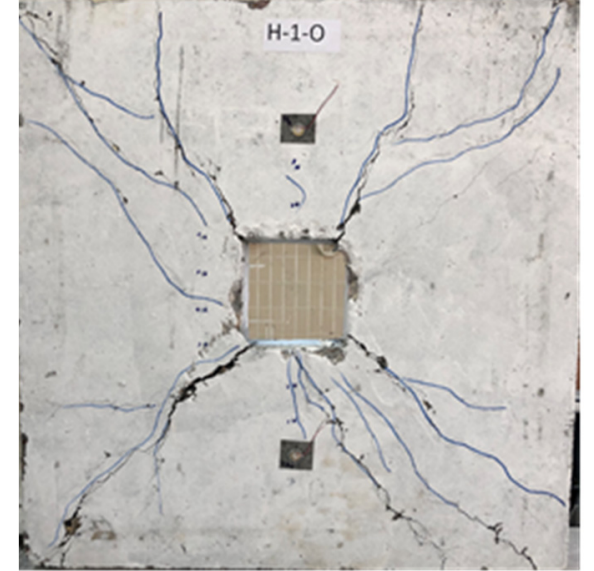

(c)

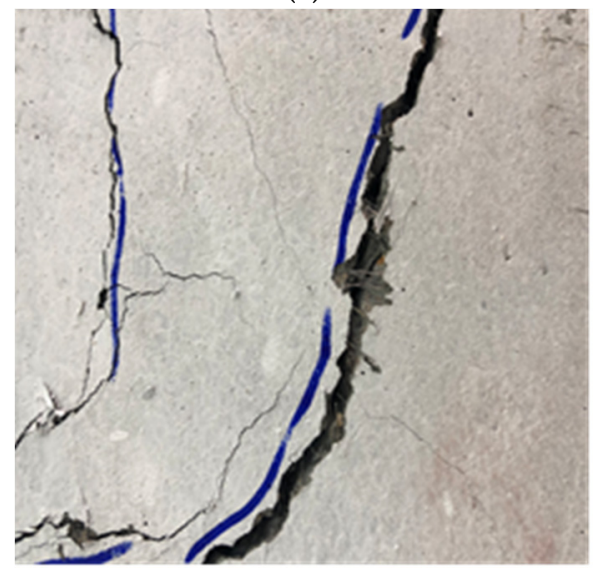

(f)

Figure 6. Crack and failure pattern of a slab with an opening. (a) Control sample without fiber; (b) Slab with straight steel fiber; (c) Slab with hooked steel fiber; (d) Slab with corrugated steel fiber; (e) Slab with polyolefin fiber; (f) Fracture failure of slab with fiber.

Cracks increased gradually until a slight stiffness reduction was noticed and crack width increased. At this stage the energy was slightly absorbed and plastic deformation begun to appear. At the ultimate load capacity of the slab, no more cracks formed, and the final failure modes were similar in all cases. The main failure mode was flexural mode because the main reinforcement of the slab was chosen to avoid punching shear.

The cracking loads for solid slabs with fiber increased by about $43 \%, 27 \%$ and $33 \%$ for steel hooked, steel corrugated and polyolefin fibers, respectively, while for the slabs with an opening, the increases in cracking loads were $10 \%, 42 \%$ and $25 \%$, respectively.

Figure 7 shows the first crack load for slabs without an opening and it is clear that the specimen with polyolefin showed extra-fine cracks coMPared with samples that had steel 
fibers with less ductile behavior. Table 7 and Figure 8 show the cracking loads for different type of fiber for slabs both with and without openings.

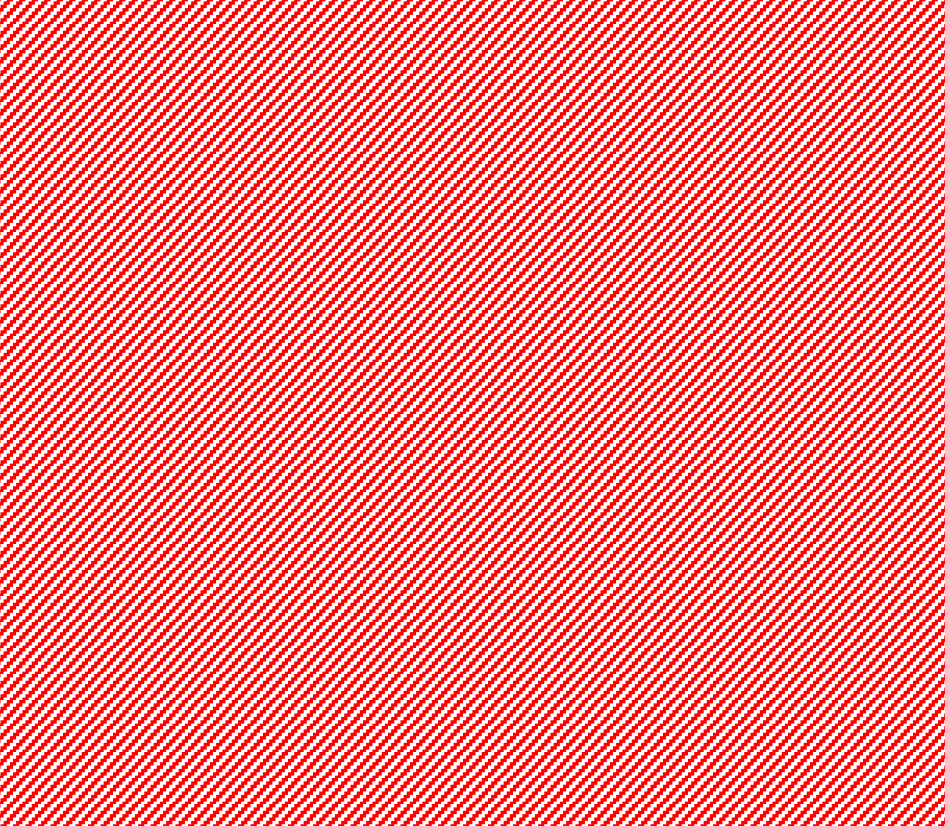

Figure 7. Cracks and failure pattern for solid slab with polyolefin.

Table 7. Cracking and ultimate load of specimens for solid slab.

\begin{tabular}{cccccc}
\hline Sample & $\begin{array}{c}\text { Pcr (Soild) } \\
(\mathbf{k N})\end{array}$ & $\begin{array}{c}\text { Pcr (Opening) } \\
\text { (kN) }\end{array}$ & $\begin{array}{c}\text { Pcr (Solid)/Pcr } \\
\text { (Control) } \\
\text { (Ratio) }\end{array}$ & $\begin{array}{c}\text { Pcr (Opening)/Pcr } \\
\text { (Control) } \\
\text { (Ratio) }\end{array}$ & $\begin{array}{c}\text { Pcr (Solid)/Pcr } \\
\text { (Opening) } \\
\text { (Ratio) }\end{array}$ \\
\hline Control & 31.5 & 32.0 & 1.00 & 1.00 & 0.98 \\
\hline H1 & 45.0 & 35.0 & 1.43 & 1.10 & 1.29 \\
\hline C1 & 40.0 & 45.5 & 1.27 & 1.42 & 1.14 \\
\hline S1 & 35.0 & 41.5 & 1.11 & 1.17 & 1.19 \\
\hline P1 & 42.0 & 40.0 & 1.33 & 1.25 & 0.95 \\
\hline
\end{tabular}

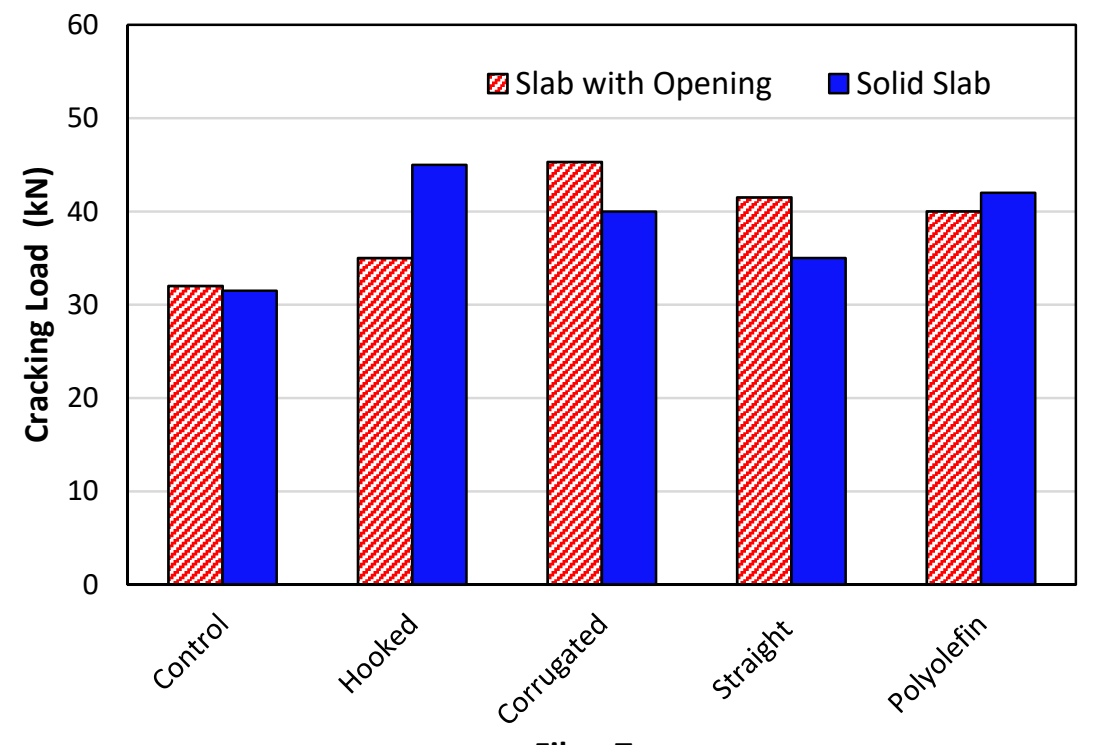

Figure 8. Effect of fiber type on cracking load. 


\section{Load-Deflection Results}

The load-deflection curves for all tested two-way slab specimens are shown in Figure 9. All the deflection values of the slabs were measured at the center of the slab. In general, the load-deflection curves start with a linear behavior as an elastic stage without cracks, followed by a nonlinear part of the curve with an elastic cracking behavior. It can be seen that the recorded deflection for samples mixed with fibers is less than those of the control slab samples, indicating that the slab structure absorbed the deformation. Using fibers in concrete mixes improves the ductility and the stiffness, but this should be within a limited volume fiber ratio as the increases in ultimate load are lower beyond a certain fiber volume ratio due to the material becoming brittle.

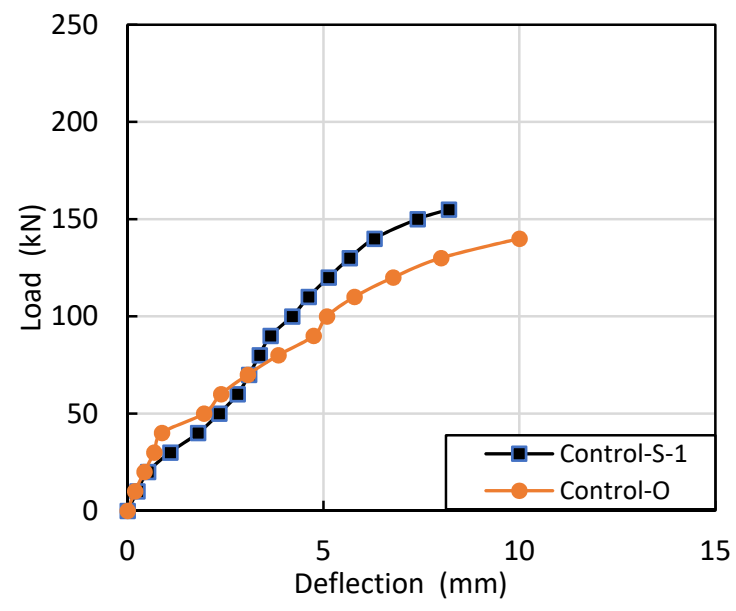

(a)

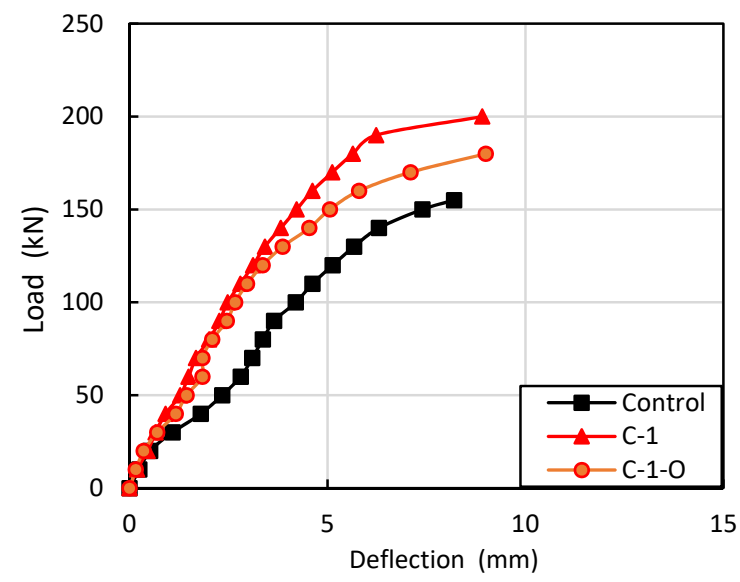

(c)

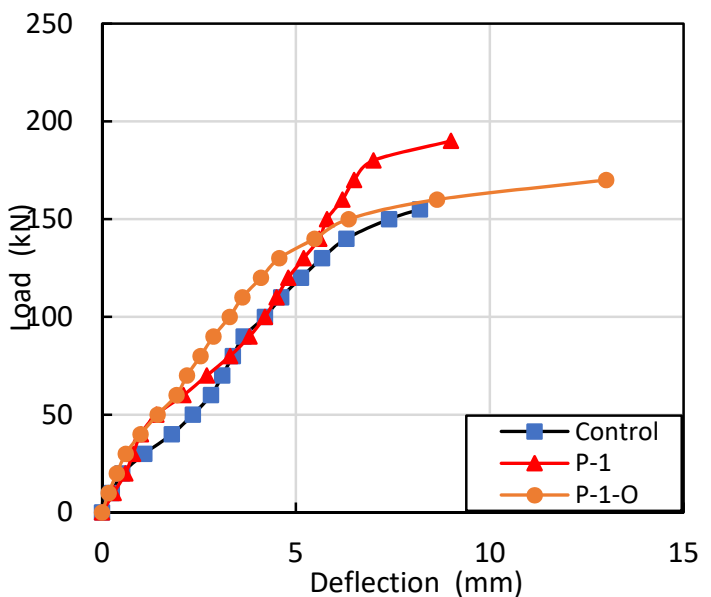

(b)

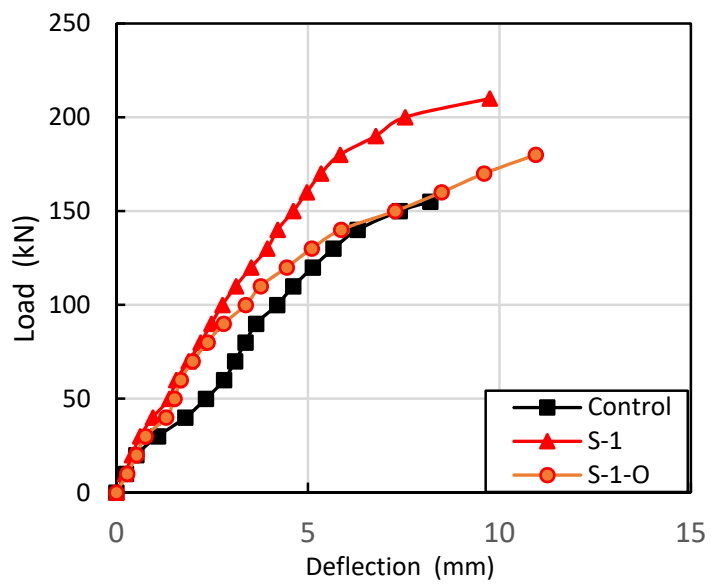

(d)

Figure 9. Load-deflection with different types of fiber. (a) Control slab with and without opening; (b) Slab with polyolefin fiber; (c) Slab with corrugated steel fiber; (d) Slab with straight steel fiber.

The control slab shows less flexural capacity strength coMPared with the other slabs with or without openings. Furthermore, the slabs with steel fiber seemed stiffer than slabs with polyolefin fiber which developed a large deflection coMPared with the control slabs and slabs with steel fibers at the final stage of failure. This is due to the increase in ductility of specimens with polyolefin.

The ultimate loads and the corresponding vertical deflections are shown in Figure 10, and the ultimate load capacity values of slab specimens are listed in Table 8. The results indicate that the reinforced concrete slabs with openings achieved extra improvement of between $13 \%$ and $25 \%$ of the capacity of the control slab without an opening. The improvement in the solid slabs with fibers varied between $16 \%$ and $44 \%$ coMPared with 
the control solid slab which indicates the slab with an opening can retain a good flexural strength capacity by using fibers as additive. From Figures 9 and 10 it can also be concluded that the slabs with openings develop larger deflections than the solid slabs.

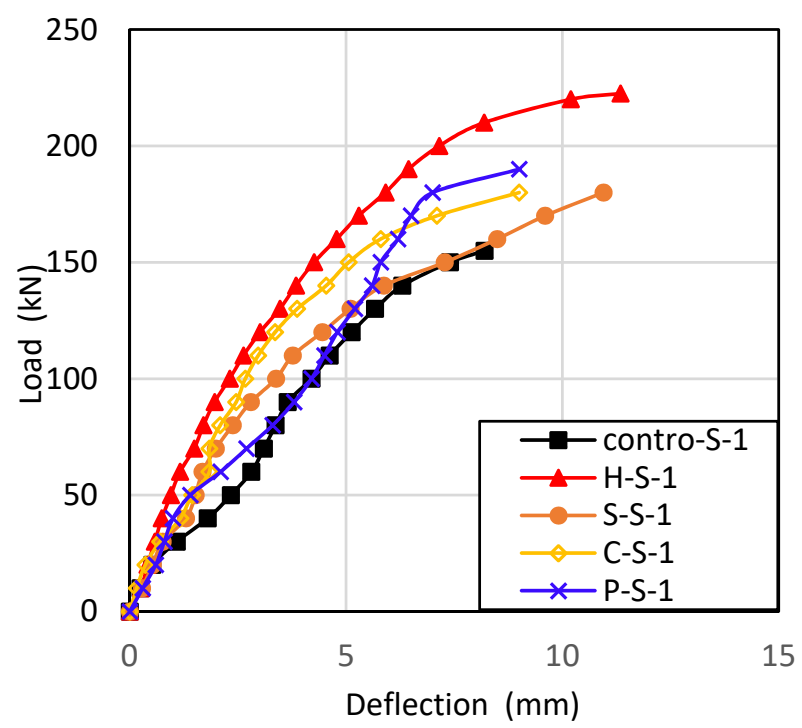

(a)

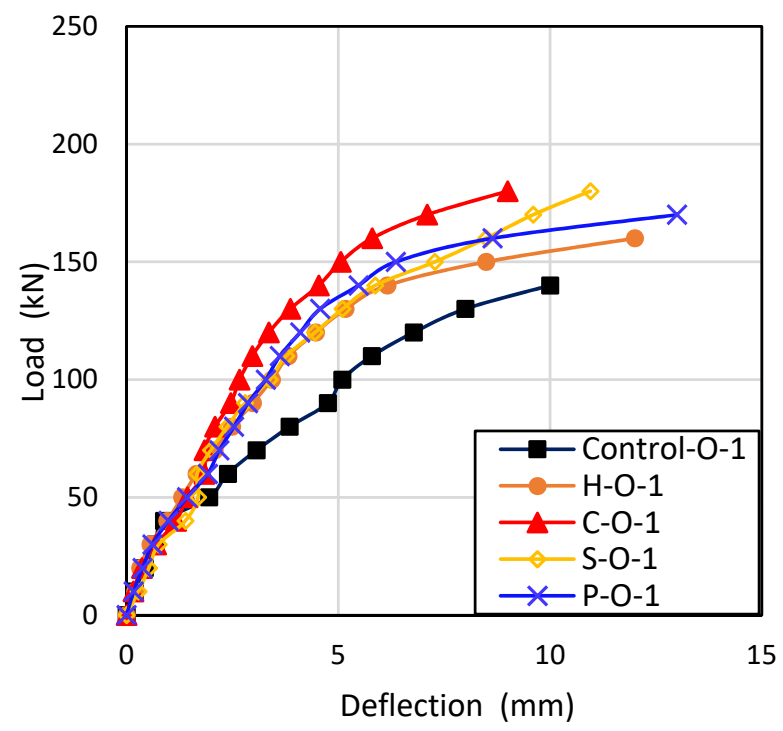

(b)

Figure 10. Load-deflection with different types of fiber. (a) Solid slab; (b) Slab with opening.

Table 8. Ultimate load of specimens for slab with opening.

\begin{tabular}{|c|c|c|c|c|c|}
\hline Sample & $\begin{array}{c}\text { Ultimate Load } \\
\text { (Solid) } \\
\text { Pu (KN) }\end{array}$ & $\begin{array}{c}\text { Ultimate Load } \\
\text { (with Opening) } \\
\text { Pu } \\
\text { (KN) }\end{array}$ & $\begin{array}{c}\text { Pu (Solid)/ } \\
\text { Pu (Control) } \\
\text { (Ratio) }\end{array}$ & $\begin{array}{c}\mathrm{Pu} \text { (Opening)/Pu } \\
\text { (Control) } \\
\text { (Ratio) }\end{array}$ & $\begin{array}{c}\text { Pu (Solid)/ } \\
\text { Pu (Opening) } \\
\text { (Ratio) }\end{array}$ \\
\hline Control & 160 & 140 & 1.00 & 1.00 & 1.14 \\
\hline $\mathrm{H} 1$ & 223 & 161 & 1.39 & 1.15 & 1.39 \\
\hline $\mathrm{C} 1$ & 180 & 179 & 1.125 & 1.28 & 1.00 \\
\hline S1 & 181 & 161 & 1.13 & 1.15 & 1.12 \\
\hline P1 & 191 & 170 & 1.19 & 1.21 & 1.12 \\
\hline
\end{tabular}

It seems that the action of fiber in concrete slabs is the ability of fibers to transmit forces through cracks, restricting the widening of the crack and reducing debonding faster. In other words, the concrete mix with fibers provides extra strength post-cracking, leading to an enhancement of the ultimate loading capacity. Furthermore, the enhancement in ultimate loads is affected by the fiber type and its distribution in the concrete matrix of the samples.

The ultimate load increment for solid slabs and slabs with an opening varies between $13 \%$ to $39 \%$, coMPared with control specimens. The improvement in specimens with steel fiber was higher than in specimens with polyolefin.

\section{Conclusions}

The effect of the type of fiber on the mechanical properties of concrete and the flexural behavior of reinforced concrete two-way slabs (with and without openings) has been investigated in this study and the result can be summarized:

1. The compressive strength of concrete modified with fibers showed that the specimen with steel fibers had improved compressive strength. The corrugated and hooked steel 
fibers showed higher improvement coMPared with other type of fibers. Polyolefin fiber slightly increased the compressive strength coMPared with control specimens. The addition of fiber had a slight improving effect on the compressive strength, varying between $11.3 \%$ to $24.8 \%$.

2. Splitting tensile strength test results suggest good enhancement for all specimens using different types of fiber in concrete mixes. Hooked and corrugated steel fiber showed the highest improvements $(94 \%$ and $77 \%)$ coMPared with a control plain specimen. Polyolefin fiber showed less improvement than steel fiber.

3. The hooked steel fiber gave the best performance of the fiber types in improving modulus of rupture, where the increase ratio was 109\% coMPared with the control specimen, whereas the polyolefin fiber enhancement was around $62 \%$. Generally, the improvement was superior in modulus of rupture.

4. The effect of fiber shape with a constant dosage of steel fibers on the flexural behavior and tested mechanical properties shows that hook steel fiber produced the higher improvement.

5. It was concluded that the cracking load increased for all sample with fibers and the highest improvement occurred for combined reinforced concrete with hooked fiber $(43 \%)$ for a solid slab coMPared with a reference slab. A moderate increment in cracking load was obtained by using polyolefin fiber (19\%). It was noticed that the flexural behavior of two-way slabs with fibers appeared more ductile. Slabs with openings presented good improvements in cracking and ultimate load while developing larger deflections than the solid slabs.

6. All the specimens failed in flexural mode due to the interaction of fibers with concrete and this combination reduced the weakness of flexural behavior, especially in slabs with an opening. Moreover, the enhancement in flexural behavior was good coMPared with control specimens due to improved ductility and delays in the progress of cracks.

7. Generally, fibers increase the bond more efficiently between concrete matrix by friction and mechanical interaction, so it is preferable to use hooked or corrugated steel fibers for flexural improvement.

Author Contributions: Conceptualization, H.K.H. and A.M.A.; formal analysis, H.K.H. and A.M.A.; investigation, H.K.H. and M.F.O.; methodology, H.K.H., A.M.A. and M.F.O.; project administration, H.K.H.; data curation, A.M.A.; resources, H.K.H. and A.M.A.; supervision, H.K.H. and M.F.O.; writing-original draft, H.K.H.; writing-review and editing, H.K.H.; funding acquisition, H.K.H., A.M.A. and M.F.O. All authors have read and agreed to the published version of the manuscript.

Funding: This research received no external funding.

Institutional Review Board Statement: Not applicable.

Informed Consent Statement: Not applicable.

Data Availability Statement: Not applicable.

Acknowledgments: The authors gratefully acknowledge the technical support provided by the Civil Engineering Department, Engineering College, University of Basrah, and special thanks goes to the laboratory staff.

Conflicts of Interest: The authors declare no conflict of interest.

\section{References}

1. Marcos, G.; Alberti, A.E.; Jaime, C.G. Polyolefin Fibres for the Reinforcement of Concrete. In Alkenes; Book Chapter 6; InTech Open: London, UK, 2017. [CrossRef]

2. Fall, D.; Shu, J.; Rempling, R.; Lundgren, K.; Zandi, K. Two-way slabs: Experimental investigation of load redistributions in steel fibre reinforced concrete. Eng. Struct. 2014, 80, 61-74. [CrossRef]

3. Grzesiak, S.; Pahn, M.; Schultz-Cornelius, M.; Harenberg, S.; Hahn, C. Influence of Fiber Addition on the Properties of HighPerformance Concrete. Materials 2021, 14, 3736. [CrossRef] [PubMed]

4. Altun, F.; Haktanir, T.; Ari, K. Experimental investigation of steel fiber reinforced concrete box beams under bending. Mater. Struct. 2006, 47, 491-499. [CrossRef] 
5. Yang, D.; Zhang, B.; Liu, G. Experimental Study on Spall Resistance of Steel-Fiber Reinforced Concrete Slab Subjected to Explosion. Int. J. Concr. Struct. Mater. 2021, 15, 23. [CrossRef]

6. Concrete Society. Concrete Industrial Ground Floors: A Guide to Their Design and Construction, Technical Report No.34, 3rd ed.; The Concrete Society: London, UK, 2003.

7. Kosa, K.; Naaman, A.E. Corrosion of steel fiber reinforced concrete. Mater. J. 1990, 87, 27-37.

8. Yin, S.; Tuladhar, R.; Shanks, R.A.; Collister, T.; Combe, M.; Jacob, M.; Tian, M.; Sivakugan, N. Fiber preparation and mechanical properties of recycled polypropylene for reinforcing concrete. J. Appl. Polym. Sci. 2015, 132, 41866. [CrossRef]

9. Fraternali, F.; Ciancia, V.; Chechile, R.; Rizzano, G.; Feo, L.; Incarnato, L. Experimental study of the thermo-mechanical properties of recycled PET fiber-reinforced concrete. Compos. Struct. 2011, 93, 2368-2374. [CrossRef]

10. Zamanzadeh, Z.; Lourenco, L.; Barros, J. Recycled steel fibre reinforced concrete failing in bending and in shear. Constr. Build. Mater. 2015, 85, 195-207. [CrossRef]

11. Son, D.-H.; Bae, B.-I.; Lee, M.-S.; Lee, M.-S.; Choi, C.-S. Flexural Strength of Composite Deck Slab with Macro Synthetic Fiber Reinforced Concrete. Appl. Sci. 2021, 11, 1662. [CrossRef]

12. Akhavan, A.; Shafaatian, S.; Rajabipour, F. Quantifying the effects of crack width, tortuosity, and roughness on water permeability of cracked mortars. Cem. Concr. Res. 2012, 42, 313-320. [CrossRef]

13. Zhang, L.; Zhao, J.; Fan, C.; Wang, Z. Effect of Surface Shape and Content of Steel Fiber on Mechanical Properties of Concrete Adv. Civ. Eng. 2020, 2020, 11. [CrossRef]

14. Denisiewicz, A.; Socha, T. Influence of Steel and Polypropylene Fibers Addition on Selected Properties of Fine-Grained Concrete. Civ. Environ. Eng. Rep. 2018, 28, 138-148. [CrossRef]

15. Lehner, P.; Horňáková, M. Effect of Amount of Fibre and Damage Level on Service Life of SFR Recycled Concrete in Aggressive Environment. Buildings 2021, 11, 489. [CrossRef]

16. Huang, Q.; Hamed, E.; Gilbert, R.I. Behavior of Concrete Sandwich Panels under Eccentric Axial Compression-Testing and Finite Element Analysis. ACI Struct. J. 2020, 117, 235-247. [CrossRef]

17. Ding, L.; He, W.; Wang, X.; Cheng, F.; Wu, Z. Flexural behavior of reinforced concrete slabs strengthened with BFRP grids and PCM. J. Cent. South Univ. 2020, 51, 1085-1096.

18. ASTM C204; Standard Test Methods for Fineness of Hydraulic Cement by Air-Permeability Apparatus. ASTM International: West Conshohocken, PA, USA, 2018.

19. ASTM C191; Standard Test Methods for Time of Setting of Hydraulic Cement by Vicat Needle. ASTM International: West Conshohocken, PA, USA, 2019.

20. ASTM C349; Standard Test Method for Compressive Strength of Hydraulic-Cement Mortars (Using Portions of Prisms Broken in Flexure). ASTM International: West Conshohocken, PA, USA, 2019.

21. ASTM C33/86; Standard Specification for Concrete Aggregates. ASTM International: West Conshohocken, PA, USA, 1986.

22. ASTM C 128-01; Standard Test Method for Density, Relative Density (Specific Gravity), and Absorption. ASTM International: West Conshohocken, PA, USA, 2001.

23. ASTM C494; Standard Specification for Chemical Admixtures for Concrete. ASTM International: West Conshohocken, PA, USA, 2019.

24. ASTM C192; Standard Practice for Making and Curing Concrete Test Specimens in the Laboratory. ASTM International: West Conshohocken, PA, USA, 2019.

25. ASTM C39/C39M; Standard Test Method for Compressive Strength of Cylindrical Concrete Specimens. ASTM International: West Conshohocken, PA, USA, 2018.

26. ASTM C496/C496M; Standard Test Method for Splitting Tensile Strength of Cylindrical Concrete Specimens. ASTM International: West Conshohocken, PA, USA, 2017.

27. ASTM C78/C78M; Standard Test Method for Flexural Strength of Concrete (Using Simple Beam with Third-Point Loading). ASTM International: West Conshohocken, PA, USA, 2018. 